\title{
UK Anti-Slavery Policy at the Border: Humanitarian Opportunism and the Challenge of Victim Consent to Assistance
}

\section{Introduction}

In 2014 the UK government launched its first Modern Slavery Strategy, sealing the UK's commitment to fighting what the current Prime Minister, Theresa May, has called 'the greatest human rights issue of our time' (May, 2016). The UK Border Force is one of only four state agencies ${ }^{1}$ to be given a 'crucial' and cross-cutting role in the delivery of this Strategy. Amongst other things, Border Force Officers have been designated as 'antitrafficking first responders', with particular duties to 'identify potential victims and provide enhanced support and protection against re-trafficking' (HM Government, 2014, p. 55). This paper examines how this new humanitarian role for the Border Force Officer has been conceptualized, justified and apparently reconciled with the aims of migration policy and border control. It draws on findings from a series of in-depth interviews with a dedicated Border Force Safeguarding and Anti-Trafficking team at the UK's largest airport to shed light on how these new duties of victim protection and support are being put into practice on the ground. The paper offers an account of the challenges to victim identification and support at the border and highlights the difficulties of addressing these for the benefit of those trafficked.

There is a growing body of criminological research investigating the pursuit of humanitarian ideals in the context of border control. However, this is focused heavily on the field of search and rescue at sea (Aas and Gundhus, 2015; Perkowski, 2016; Squire, 2017). In

\footnotetext{
${ }^{1}$ The other three agencies are the police service, the National Crime Agency, and the Gangmasters and Labour Abuse Authority- the agency responsible for preventing, detecting and responding to cases of labour exploitation, though the role of this latter agency is limited as it only operates across a small number of sectors.
} 
comparison, anti-trafficking victim identification and support is still a nascent area of humanitarian border control. As a result, empirical studies of how such efforts play out at the border remain few and far between (Ham et al, 2013; Pickering and Ham, 2014). This paper attempts to address this relative lack of insight into anti-trafficking first response at the border.

Our analysis also takes forward critical debates about the coherence of humanitarian antislavery policy and the consistency of its ambitions with a continued prioritization by governments of security policy and immigration control. In particular, our analysis lends support to O'Connell Davidson and others, who argue that strict migration and security policies increase the economic and social vulnerability of some migrant groups and thereby exacerbate the structural drivers of trafficking (O'Connell Davidson, 2015, 2017; Sharma, 2017). In doing so, it casts doubt on the view expressed in the policy discourse and beyond (McAdam, 2013; HM Government, 2014; UN OHCHR, 2010), that a human-rights approach to anti-trafficking or anti-slavery policy at the border is practically achievable.

The UK government has only recently adopted the term 'modern slavery' to describe what had previously been referred to as 'human trafficking' or 'trafficking in persons'. In so doing, it has aligned its Modern Slavery Strategy with what has become known as the 'new abolitionist' movement, pioneered by activist and academic Kevin Bales. This move has been criticized vigorously, most notably by Julia O'Connell Davidson, who has argued that the conceptual shift away from trafficking to slavery presents the phenomenon as a problem of moral wrongdoing by individuals (or 'evil' in the words of the UK's current Prime Minister 
[May, 2016]) and in so doing elides questions of state-sustained structural conditions, which enable large-scale coercion and exploitation.

As our analysis supports O'Connell Davidson's position, we continue to use 'human trafficking' instead of 'modern slavery' when doing so does not misrepresent the positions or agents we discuss. Similarly, we are cognizant of the problematic aspects of using the word 'victim' to refer to people who may themselves reject such a label. Indeed, we deal with this issue directly in Part II of the paper. Where possible, then, we speak of 'those trafficked' or 'those identified as victims' rather than 'victims of trafficking'.

\section{Background}

According to the UK government, Border Force Officers are uniquely well-placed to act as anti-slavery first responders because: 'victims who are trafficked will often cross our borders and we need to use that opportunity to identify them and to intervene' (Independent Chief Inspector of Borders, 2017: 6.14). Yet 3 years on from the publication of the UK's Modern Slavery Strategy, the figures reveal a startling disparity between government's expectations of Border Force as an agency of first response and the reality on the ground. For in 2016, less than $2.9 \%$ of the 3805 referrals made in the UK came from Border Force. ${ }^{2}$ What might explain the disparity between the government's expectations of the Border Force and the reality on the ground, and how should it be addressed?

Official responses to this question tend to focus critical scrutiny on Border Force performance rather than on the expectations placed upon them (and indeed on other first responder agencies) by the government. They imply that the success of victim identification

\footnotetext{
2 The National Crime Agency (NCA) End of Year Summary 2016 shows that of the 3805 people referred to the National Referral Mechanism, only 111 were referred by UKBF. 94\% of those 3805 were non-UK citizens.
} 
and protection is ultimately down to the anti-slavery first responder. For example, the first ever review of anti-slavery at the border, published in 2017, opens with an admonition of Border Force to take more seriously its anti-slavery role:

'Border Force has a duty and responsibility to respond to the crime of slavery with urgency and efficiency, as recognised in the UK Government's Modern Slavery Strategy...Modern slavery is not simply a matter of numbers, targets and processes for Border Force to manage; human lives are at stake and people's freedom is in question' (Kevin Hyland, UK Independent Anti-Slavery Commissioner in Independent Chief Inspector of Borders, 2017).

The author of that report, the government-appointed Independent Chief Inspector of Borders, recognises that victim identification and protection is challenging; but he ultimately highlights deficiencies in Border Force practice to explain the current low rate of success. Similarly, his recommendations for improvement relate solely to Border Force practice, including better training, information-keeping and decision-making (Ibid, 2017 p.3). The message conveyed is that, if only Border Force Officers took their responsibilities seriously, followed the guidance, and were well enough trained, victims would be better identified and protected.

In this paper, we present research that tells a different story. Our aim is not to cast doubt on the claim that there is room for improvement in Border Force practice in this area. Rather, it is to draw attention to some of the serious constraints faced by Border Force Officers in their efforts to meet the expectations placed upon them as first responders and, in doing so, to shed critically constructive light both on those expectations and on the government's approach to anti-slavery first response more broadly. Our analysis, which draws on relevant 
policy documentation and a series of in-depth interviews with a dedicated Safeguarding and Anti-Trafficking team at the UK's largest airport, shows how the government's anti-slavery expectations are underpinned by a distinct normative rationale, which aims to render the objectives of migration policy consistent with the protection of those vulnerable to human trafficking. This rationale, which we conceptualise as a kind of 'humanitarian opportunism', grounds anti-slavery obligations not in the role of the professional but in the contingent existence of opportunities to help-in this case, to 'save' others. We identify two distinctive and problematic ways in which humanitarian logic is being employed to justify anti-slavery first response at the border. First, it rests on ungrounded assumptions-both about the existence of genuine opportunities to identify and offer support to those identified as victims, and about the ultimate value of the support on offer. Second, it is used by the government in order to justify the co-option of Border Force Officers into the pursuit of policy causes that not only lie outside the normal scope of their professional remit but actively conflict with it, as we claim is the case with respect to the competing demands of victim response and immigration control at the border. We contend that this results in the imposition by the Modern Slavery Strategy of demands on Border Force Officers that are competing but irreconcilable in ways that changes to their practice alone cannot resolve.

Moreover, we argue that the deployment of this rationale at the border is paradigmatic of an increasingly frequent appropriation by security and governmental agents of humanitarian and human rights discourse in order to reframe and justify the pursuit of other, potentially conflicting, policy aims, in this case migration and crime control. In doing so, we lend support to recent literature on migration and border control which criticises this blurring or elision between the pursuit of security and humanitarian policy aims as 
incoherent and potentially damaging to vulnerable people (Perkowski, 2017; Sharma, 2017;

Pickering and Ham, 2014; Aas and Gundhus, 2015; Hadjimatheou and Lynch, 2017).

The paper is structured as follows. Part I analyses the UK government's modern slavery agenda, provides an account of the role of Border Force within it, and articulates and develops the concept of humanitarian opportunism. The arguments put forward in this section are supported primarily by means of examination of policy documents and academic literature. In Part 2 we present the methodology for our study with a Border Force antitrafficking team at London's Heathrow airport and discuss the findings. We identify two distinct challenges faced in the implementation of anti-slavery first response at the border. The first relates to the fact that in practice EU freedom of movement exempts the majority of people trafficked into the UK from being risk-assessed for indicators of vulnerability by Border Force Officers. The second relates to the fact that current policy makes the provision of assistance to those trafficked dependent on their consenting on the spot to being formally registered as a 'victim' of trafficking 'crime'- something many of those trafficked are understandably reluctant to do. The paper concludes by reflecting on what these findings imply about the gap between the aspirations and likely achievements of antislavery policy at the border, and the compatibility of humanitarian agendas and migration and crime control more broadly.

Part 1: The UK's Modern Slavery Strategy at the Border: The Logic of Opportunity 
The designation of Border Force Officers as 'trafficking first responders' (Home Office, 2016b) has come about despite the fact that neither their professional culture as a law enforcement agency, nor their prior training or experience has involved significant focus on the protection of vulnerable adults. The rationale for this move is that borders present a site of 'unique opportunity to identify victims' (Chief Inspector of Borders, 2017). The opportunity is presented as arising in one or more of three ways. First, those trafficked are often brought into the country from abroad, at which point Border Force Officers are likely to encounter them. Second, Border Force Officers are often said to be the last figures of authority to come into contact with people who have been trafficked before they 'disappear' into exploitation; their contact with those trafficked thus presents a (potentially) final chance to prevent that exploitation from occurring (Centre for Social Justice, 2013). Third, Border Force Officers have considerable powers of question and search under immigration and customs regulation. The value of these powers in helping to uncover 'indicators of trafficking' is said to put Border Force Officers in a strong position to be able to identify those trafficked. As the Executive Director of the EU border agency Frontex declares in his foreword to their anti-slavery training manual: '[B]order control - with its systematic checks - has a unique role and ability to intervene, prevent and combat trafficking in human beings' (Frontex, 2012: 7).

According to this logic of opportunity, the primary challenge to successful victim support at the border is not finding those trafficked, but learning to recognise them. People who are being trafficked, it is often pointed out are 'hidden in plain sight' (Anti-Trafficking Monitoring Group, 2013), circulating amongst otherwise indistinct populations, doing work that appears normal to observers (Local Government Association, 2017). Border Force's main anti-slavery activity is thus raising awareness amongst officers of the 'need to be alert 
to the risk and to the signs to look out for' and then training them to recognise those signs (Independent Chief Inspector of Borders, 2017; Frontex, 2012). The emphasis on awareness, identification, and recognition is apparent throughout the Strategy and its agency-specific related documents. We shed critical light on this emphasis later in this paper, suggesting that these initial forms of intervention are of questionable value if implemented without sufficient provision of longer-term protection, compensation, and support. At this point, however, we explore in more depth how the government grounds these duties of recognition in a logic of opportunity.

Border Force Officers are designated as 'anti-trafficking first responders' by the Home Office not because border control relates in some fundamental way to the protection of human rights, nor because ports and border crossings are sites of exploitation, but rather, 'based on the likelihood that they would encounter potential victims' (Independent Chief Inspector of Borders, 2017). Thus it is the sheer flows of people passing through border control, amongst whom there will inevitably be people who are being trafficked, that creates an imperative to intervene.

The opportunity to intervene is presented as something more profound than merely a chance to contribute to the pursuit of a governmental priority; namely, a possibility to save another human being from enslavement. This portrayal of anti-slavery as serving an urgent moral cause reflects a well-established consensus both in normative human rights theory and in human rights movements: that the protection of basic human rights should take precedence over (or, in the language of political philosophy, should 'trump' [Dworkin, 1984]) the exigencies of other governmental priorities, such as migration control. But its real strength as a motivating rationale lies in its universality and its pre-theoretical moral appeal: 
there is no need to refer to religion, political values or professional codes to explain why we should all be ready to help those in dire need; it is a basic duty of care we all owe to each other as human beings. This kind of supportive rationale is essential for the success of the anti-slavery strategy, because it enables the government to bypass any professional inexperience or qualms officials may have in taking on the mantle of first responder and appeal to their better nature instead.

The reality remains, however, that Border Force Officers are being co-opted into state agendas that not only radically diverge from, but also potentially conflict with, the purpose of their profession. ${ }^{3}$ There is now a requirement to sort people at the border on the basis of their vulnerability, ${ }^{4}$ rather than their immigration status. This is presented as continuous with the values and priorities driving frontline Border Force work, yet it in fact entails a significant shift from them. As has long been pointed out by theorists of surveillance, borders are paradigmatic sites of social sorting (Lyon, 2007; Aas, 2011). The primary criterion of distinction for such sorting is immigration status. The inculcation of a humanitarian anti-slavery agenda into border control challenges the prevailing logic of the border by requiring border officials to approach travellers 'primarily as... individuals with protection and assistance needs [rather than as] threats to border integrity' (McAdam, 2013: 46). In other words, it requires Border Force Officers to be both attuned to and to

\footnotetext{
${ }^{3}$ The co-option of law enforcement officers into safeguarding agendas is also occurring in the context of the UK's 'Strategy to end violence against women and girls 2016-2020', under which police have acquired similar responsibilities to identify and safeguard vulnerable individuals. An example of specific responsibilities can be seen in the Mayor of London's Strategy, which allocates protective duties to the Metropolitan Police, see: https://www.london.gov.uk/sites/default/files/vawg_strategy.pdf

${ }^{4}$ There has always been a requirement to look out for vulnerable children because children have always had a distinct, protected status in the law. But this has also been controversial in practice, as it often involves efforts to determine the age of those arriving in ways that visit suspicion and intrusive scrutiny on them (McLaughlin, 2017).
} 
respond primarily to the vulnerability of travellers, irrespective of their immigration statusthus inverting the priorities of border control. What is more, this apparently radical attempt to co-opt border officials into humanitarian policy agendas is presented as compatible with the work of immigration control, rather than disruptive or subversive of it. As McAdam explains in her defence of a human rights approach to border control:

A rights-based approach to border control acknowledges the core work of border officials as being to uphold border integrity, while ensuring that their performance of this role does not jeopardize the rights of those they intercept nor result in missed opportunities for specialists to identify trafficked persons and other vulnerable people among them. (McAdam, 2013: 33)

The idea that the work of border control is compatible with a proactive humanitarian antislavery policy is supported within Border Force as a logical extension of well-established, existing law and practice around child protection. Indeed, the new 'Safeguarding and AntiTrafficking' teams are in fact expanded and rebranded versions of longstanding Child and Youth Protection Teams. In what follows we cast serious doubt on the extent to which the reconciliation between border control and humanitarian anti-slavery work imagined by McAdam is achievable and discuss in detail some of the problematic consequences of the conflation of vulnerable adults with children by Border Force.

For now, however, let us focus on the organisational response to the Modern Slavery Strategy, which appears to be ambivalent with respect to whether safeguarding and antitrafficking should or should not be a core competency of border control. While Border Force has implemented mandatory basic training in anti-slavery law and policy for Border Force 
Officers, it seen by many as a tick-box exercise. Indeed, the recent inspection of Border Force reveals that the organisation has not been monitoring let alone enforcing the uptake of this training, with some designated Safeguarding and Anti-Trafficking officers not having received any relevant training at all (Independent Chief Inspector of Borders, 2017). Indeed, the imposition of a humanitarian role on the Border Force has met with internal resistance from some Officers, who see their role beginning and ending with the enforcement of the border (Authors, 2017). Some Border Force Officers want to keep the lines between security and immigration policy and safeguarding/humanitarian work clear in the face of increased blurring of the discursive boundaries between these categories. Thus in practice Safeguarding and Anti-Trafficking work seems to be undertaken on a largely voluntary basis, via specialised Safeguarding and Anti-Trafficking teams, which take on the role of interviewing and dealing with those identified as 'potential victims of trafficking' or PVOTs (Ibid.).

This apparent ambivalence has been challenged by the UK's Independent Anti-Slavery Commissioner. According to his assessment, implementation of the Modern Slavery Strategy requires that professional commitment to the anti-slavery role be demanded from Border Force Officers across the board (Hyland, K. in Independent Chief Inspector of Borders, 2017). Only then, he argues, can the force meet its responsibilities to 'disrupt modern slavery at our borders and ultimately ensure those traded as human commodities are protected' (Ibid.).

In the following section, we argue that the protection of victims at the border would likely continue to fall well below expectations even if these responsibilities were met. This is 
because the possibilities for effective protection are determined not only by the extent of institutional buy in and streamlined practice, but also on the existence of genuine opportunities to provide genuine help, neither of which are sufficiently present at the border.

\section{Part 2: Humanitarian opportunism in action: anti-slavery first response at the border}

So far, we have examined the role of the Border Force in the UK government's Modern Slavery Strategy in a relatively abstract, 'top-down' way. In this section we shift perspective and examine it from the bottom up, through the views of officers actively engaged in antislavery border work on the ground. In what follows we present findings from a series of indepth interviews with members of a single Safeguarding and Anti-trafficking team at London's Heathrow Airport.

We approached Heathrow because it is the busiest airport in the UK, has taken more concerted efforts- through training, resourcing, and the development of good partnership working amongst other things- to prioritise anti-slavery than any other airport, and has the largest UKBF Safeguarding and Anti-Trafficking team in the country, comprising 15 officers when the study took place. All the Safeguarding and Anti-Trafficking officers we spoke to had received both the mandatory online training and attended a specialist 4-day course. In contrast, it is reported that some ports in the UK had designated individuals as Safeguarding and Anti-Trafficking officers despite their having received no Safeguarding and AntiTrafficking training at all (Ibid. 3.6). Heathrow has also seen higher numbers of identifications of 'potential victims': more than all other ports put together in the period 
2014-15 (Independent Chief Inspector of Borders, 2017, 8.3 fig.6). ${ }^{5}$ Nevertheless, we note the difficulty in assessing the relative success of Safeguarding and Anti-Trafficking initiatives due to a recognized paucity of published data, particularly in relation to the numbers of potential victims identified and referred to the National Referral Mechanism ${ }^{6}$ (the UK's official process for identifying victims of human trafficking or modern slavery and referring them upwards to the authorities for formal recognition as trafficked and provision of assistance) (Independent Chief Inspector of Borders, 2017; Lynch and Hadjimatheou, 2017).

We undertook semi-structured interviews with 10 officers in total: 9 members of the Safeguarding and Anti-Trafficking team and one officer who was intending to train. ${ }^{7}$ Data collection was carried out by the authors and took place on-site at Heathrow Airport in May 2015 following full ethical approval from the University of XXX's Research Ethics Committee on 14 November 2014 (ref. 40/14-15). Each interview was recorded and typically lasted for 60-90 minutes. Our sample of research participants was necessarily small due to the focus on the relatively few Border Force Officers who had received Safeguarding and AntiTrafficking training at the time. Our fieldwork was also limited by the impact of general Border Force staff shortages on rotas, meaning that we were unable to interview the entire Safeguarding and Anti-Trafficking team in the allocated time. Restrictions on time and budget (this research was a small part of a larger programme of work) inevitably shaped our

\footnotetext{
${ }^{5}$ Though not as high a rate of referral to the National Referral Mechanism as at other ports. It is difficult to draw reliable conclusions from these discrepancies. While a higher rate of referral might indicate a more successful approach, it was reported in the recent Inspection (Independent Chief Inspector of Borders, 2017) that some ports were referring all clandestine travellers to the National Referral Mechanism, only for such referrals to be rejected at the earliest stage.

${ }^{6}$ National Referral Mechanism referral form for adult victims of trafficking, 2016. At https://www.gov.uk/government/uploads/system/uploads/attachment data/file/631200/Adult-NRMv.3.0.pdf

${ }^{7}$ This participant provided a sympathetic but external view of the team, its purpose, and motivations for joining.
} 
methods and limited the scope of our research. For example, previous studies on border policing have engaged in ethnographic observations to understand more fully the actual practice of border force officers (Loftus, 2015; Pickering \& Ham, 2014). Future research into safeguarding and anti-trafficking activities at the border would benefit from a similar approach to explore how potential victims of trafficking are identified and dealt with on a daily basis. Nevertheless, to our knowledge this study was the first -and remains the onlyof its kind to interview Border Force Officers engaged in Safeguarding and Anti-Trafficking work in the UK about their experiences of this novel duty.

The officers we spoke to were both senior and junior-most were responsible for dealing with safeguarding and/or trafficking issues referred to them on a day to day basis by other immigration officers; but we also interviewed the officer managing Safeguarding and AntiTrafficking intelligence and the strategic lead for safeguarding and trafficking at Heathrow. Eight of the 10 officers were women, and both of the men were at the start of their careers.

Our approach to data collection and analysis was influenced by the narrative tradition in social research: posing minimal and open-ended questions intended to provoke reflection and discussion from Border Force Officers about their individual experiences of the jobprimarily what their work meant to them and what aspects of it they found challenging or rewarding. Example questions included:

1. Could you tell us about the safeguarding and anti-trafficking work you do?

2. What kind of challenges are there to trying to identify victims of trafficking at the border?

3. How do you feel about your work in the SAT team? 
Narrative approaches look beyond questions of truth and consistency to exploration of 'the complex nature of values, identities, cultures, and communities' (Sandberg, 2010: 448). Analysis was therefore driven by the need to theorise from the narratives intact to understand how our participants created meaning and made sense of their roles as Border Force Officers (Etherington, 2004). We also undertook thematic analysis to identify shared experiences. ${ }^{8}$ By prioritizing the perspectives and voices of Border Force Officers, our approach helps us gain insight into the 'culture and practices of those involved in the daily upkeep of border priorities' which, despite notable exceptions (Aas and Gundhus; 2015 Pickering and Ham, 2014; Pratt and Thompson, 2008), remains largely undertheorized, as noted by Loftus (2015: 11). In taking this approach, we did not seek corroboration of our participants' accounts through other methods of validation. Border Force Officers spoke candidly about their experiences but we acknowledge that they told us the 'stories' they wanted us to hear, and those perspectives may have been influenced by their motivations for participating in the research. For example, senior officers in the Border Force were keen to promote the work of the Safeguarding and Anti-Trafficking team and potentially use the research project to make contacts with teams doing similar work in other ports. Although efforts have been made to report the data of individuals in a confidential way, participants were aware that the identity of Safeguarding and Anti-Trafficking team would be disclosed. The Safeguarding and Anti-Trafficking officers we spoke to were not typical of Border Force Officers at Heathrow, but had self-selected into the anti-slavery role for a range of personal and professional reasons that would-inevitably and understandably-not be present for others. For example, a core number (4) of those longest serving Border Force Officers that

\footnotetext{
${ }^{8}$ We reported on the occupational culture of the team in our previous paper (ref to be supplied)
} 
we spoke to had been members of the Heathrow Child and Youth Protection team which had preceded the formation of Safeguarding and Anti-Trafficking team. As we illustrate further below, these distinctive aspects make the perspectives of the Safeguarding and AntiTrafficking team indispensable to understanding persistent, organizational and structural challenges to anti-slavery at the border. In particular, the perspectives of Safeguarding and Anti-Trafficking officers are not clouded by cultural and professional resistance to the antislavery agenda; on the contrary, they demonstrate precisely the kind of deep moral and professional commitment to the humanitarian cause propounded in the Modern Slavery Strategy and which the Anti-Slavery Commissioner identifies as vital to successful victim protection. This was illustrated in many of their responses to the question with which we opened our interviews, which asked them what their job means to them. For example, one Safeguarding and Anti-Trafficking team member replied thus:

Some people don't want to deal with [safeguarding and anti-trafficking work] because they just can't deal with it. It's just one of those things. Personally, I like my job. I like helping people... [Before Safeguarding and Anti-Trafficking training was rolled out to senior staff] Chief Immigration Officers wouldn't take me seriously. And I'm trying to push, saying that this is a safeguarding issue, we need to do this, we need to do that. And then some ClOs are, like I said, just like officers, they just think about immigration and they just want to get that person off the [passport] control [desk]: "wherever they go, it's fine, up to them", you know. I had too many brushes with not very nice ClOs [laugh] who were not listening to us about the safeguarding things... the training is now disseminated to all levels, so they're becoming a bit more understanding. [P4]

Similarly, another Safeguarding and Anti-Trafficking officer told us: 
I'm here to protect the border but I'm also here to protect vulnerable adults and children. ... I think really people don't believe that we are here to protect... I don't think people believe that we're here to protect the vulnerable and the children. Yes, we will maintain how we are, and the officers on the Safeguarding and Anti-Trafficking team here, they are dedicated... they will fight tooth and nail to make sure that child is safe, no matter what. Even if they get complaints in, right, don't care. You can complain about me, as long as I know that child is safe, you can complain as much as you like... [P9]

These self-descriptions by officers suggest that, for them, anti-slavery work is not, as the UK's Independent Anti-Slavery Commissioner suggests 'simply a matter of numbers, targets and processes for Border Force to manage (Hyland, K., UK Independent Anti-Slavery Commissioner in Independent Chief Inspector of Borders, 2017). Rather, as the above quotes show, they are keenly aware of the fact that 'human lives are at stake and people's freedom is in question' and go to significant lengths to identify those trafficked and fulfil their 'duty and responsibility to respond to the crime of slavery with urgency and efficiency, as recognised in the UK Government's Modern Slavery' (Ibid.)

Let us turn, then to consider their views on the key challenges facing effective anti-slavery first response at the border.

Challenge 1: Where's the opportunity? EU exceptionalism means immigration trumps vulnerability once more. 
In their 2011 analysis of anti-trafficking and the Border Force, Balch and Geddes suggested that 'measures to enforce immigration rules and the economic rationale of selection that has informed 'managed migration' policy in the UK may not rest easily with approaches that seek to recognise and protect the victims of trafficking'. (2011: 28) The tension they had in mind, and which is often highlighted in the anti-trafficking literature, arises because many of those trafficked qualify also as illegal migrants; thus political pressure to reduce illegal migration risks fuelling the miscategorisation of those trafficked as (mere) illegal migrants at the cost of recognizing their safeguarding needs (Goodey, 2003; Aradau, 2004; Massey and Collucello, 2015; O’Connell Davidson, 2017).

In this section we highlight a different and until now unacknowledged tension between immigration control and anti-slavery at the border. Unlike the well-documented tension that arises between the protection of victims of trafficking and the strict enforcement of immigration control, the tension we wish to draw attention to arises when immigration controls are removed, namely for European citizens. Here, the risk is that those trafficked are miscategorised as mere legal migrants, leading to a failure to identify them and offer them support. Indeed, European freedom of movement was cited by the Safeguarding and Anti-Trafficking officers we spoke to as the principal challenge to their ability to identify victims at the border (Authors, 2017). ${ }^{9}$

There is nothing in immigration regulation that prevents Border Force Officers stopping and questioning EEA nationals at passport control, nor is there any clause absolving them of

\footnotetext{
${ }^{9}$ Despite reporting that it is impossible to help EU PVOTs without special operations, Border Force Officers also gave us 3 examples of EU citizens being identified at the border as PVOTs. The inconsistency is, in our view, only apparent, however. For these examples were clear outliers, involving as they did an unaccompanied white Finnish minor wearing a burka; a woman who was accompanied by someone already known to Border Force as probably trafficked for sexual exploitation; and a woman who self-presented as trafficked.
} 
their obligation to take proactive measures to identify victims of trafficking if they present at borders with EEA passports. Rather, the difficulties arise at the level of supranational policy because officers are instructed to refrain from acting in ways that have the effect of restricting the flow of EEA travellers. As the participant quoted above describes, in practice, freedom of movement is interpreted as guaranteeing movement through border that is not only free, but fast.

As this suggests, the primary challenge posed to Safeguarding and Anti-Trafficking work by EU freedom of movement lies in the restrictions it poses on the ability of officers to probe and question travellers in order to uncover indicators of vulnerability. In contrast to the thorough questioning and detailed inquiries they described undertaking in order to assess the vulnerability to trafficking of 'third country' citizens, processing of European citizens is restricted to a 'cursory' authentication of identity, at best. Thus EU freedom of movement reduces the opportunity to detect initial indicators of vulnerability and to gather further evidence of victimhood.

The irony of a situation in which Safeguarding and Anti-Trafficking officers are admonished to think like first responders but then prevented from acting as such is not lost on the Border Force Officers we spoke to:

We are told that we are not supposed to ask many questions from EU nationals and Brit nationals. Safeguarding actually supersedes that, we are supposed to ask questions, and we often are in conflict, immigration and safeguarding. ...Now when you've got the e-gates coming into play and more use of them, I think they're bringing in even more now, and possibly opening them up for minors to use as well, it's going to create all sorts of issues relating to Safeguarding and Anti-Trafficking. ... the only 
criteria is that you're European, over the age of 18 and hold an electronic passport. So a vulnerable adult could easily slip through. [P1]

EU freedom of movement at borders has the effect of creating a category of traveler that is exempt from anti-slavery monitoring on the basis of their immigration status. Thus we see a situation in which immigration status once again overrides vulnerability as the criterion of distinction at borders, in direct conflict with the government's logic of humanitarian opportunism that has been so enthusiastically adopted by the Safeguarding and AntiTrafficking team at Heathrow. Perhaps unsurprisingly, given the contradictory messages coming from the authorities, there was a palpable sense of frustration amongst those we spoke to about the opportunities lost. This was compounded by an awareness that the majority of those trafficked into the UK are from other European countries.

I think especially on the European channel, because mostly that's where it's coming through, I think that we should be given more powers to stop and interview European passengers. We should be given that, I believe in that. We would be helping a lot of people, yeah. [P6]

The concern that freedom of movement is tying the hands of Safeguarding and AntiTrafficking officers with respect to the largest source of the flow of victims is supported by official estimates. According to a United Nations Office of Drugs and Crime report, $61 \%$ of identified or presumed victims in the EU originated from EU member states (quoted in European Parliamentary Research Service, 2014: p.3) A more recent Eurostat report puts the estimate of registered victims from within the EU at 65\% (Eurostat, 2015: p.11).

These findings challenge the view that a failure amongst border officers to be alert to and recognize those trafficked as victims are the main obstacles to identification and protection 
at the border. They reveal instead the contradictory nature of the expectations currently imposed on Border Officers by the merging of their duties with respect to immigration policy and anti-slavery policy. This belies the view, expressed in the policy discourse and beyond (McAdam, 2013), that a human rights approach to border control is compatible with the strict enforcement of immigration policy, even when such policy is permissive rather than exclusionary. It suggests that, while it is important to recognise individuals as needing interventions that both tackle their vulnerability and their status as a potential threat to border security this is unlikely to be achievable through the expansion of BFO role to accommodate what remain contradictory aims.

At this point, it is pertinent to address an issue that cannot but have already arisen in readers' minds, namely Britain's imminent withdrawal from membership of the European Union. It is highly likely that European exemption from border control will end before 2020 . While it is premature to speculate on what this will mean for anti-slavery strategy, let us assume that the challenge posed by freedom of movement is a temporary one, and that Safeguarding and Anti-Trafficking officers will soon be able to exercise the full range of their powers and skills with respect to this group of travelers. Would the existence of a genuine opportunity to identify victims automatically translate into genuine opportunities to help them? In the next section, we present findings suggesting that it would not.

\section{Challenge 2: Getting consent to assistance: between resistance and rationalisation}

In the previous section, we suggested that opportunities to identify those trafficked at borders are severely constrained by immigration policy in the form of EU freedom of movement. In this section, we argue that, even where identification does occur, the scope for genuinely helping those trafficked is far more limited than is often implied. We identify 
the source of those limits as lying within UK anti-slavery policy itself. We highlight these via an examination of the requirement on Border Force Officers to obtain written consent from those identified as trafficked to being formally designated as victims as a condition of assistance.

The requirement to obtain consent is a fundamental pillar of the 'human rights approach' to anti-trafficking victim response, and is presented as a self-evident way of ensuring that the agency of victims is respected in the anti-trafficking process (UNOHCHR, 2010). Yet, evidence shows that the majority of those identified as victims at the border in fact refuse to consent to official referral for assistance through the National Referral Mechanism (Independent Chief Inspector of Borders, 2017). Our conversations with Safeguarding and Anti-Trafficking officers revealed that the consent requirement was, in their view, the second most serious obstacle to effective victim protection at the border:

Our problem is we encounter these people before exploitation has occurred. And they might even not recognise that they're being coerced or they're scared to tell us, because they've been told that... their family members might be threatened and things like that. So they won't tell us... There was a Latvian who come through in her twenties. She was with another female a bit older than her. And we believed that both of them were potential victims of trafficking, but one had been in the game a lot longer than the other one. But both of them [...] refused to be taken into the National Referral Mechanism because they were both scared. And we couldn't do anything. All we've done is basic intel, so that if they're encountered again, you know, we know what to do, we can recognise that. We can keep putting it to them, saying that 'you're a PVOT, you're a PVOT', but they're too scared sometimes to come forward... and if 
they don't consent, then that's it, they're lost, we can't do anything to help them unless they're picked up by police later on. And even then, they'll probably just abscond from there because they're that scared because of that cycle of abuse.

So I wish there were more powers that we could do, because we identified that Latvian, I wish that we could have just said, 'no, we can take you away from here'. But things like that are not immediately resolved. It takes...it's a long process. [P1]

And another, more experienced officer told us:

Well, no one's going to admit they're vulnerable. Nobody's going to admit that, oh, somebody's doing... If that person's frightened of the individual who brought them here, they're not going to say nothing. And no matter what you say, it isn't going to happen. [P9]

And most of them will say no, I'm not being trafficked. Because it's before exploitation has occurred. So they think they're coming here to have a better life. ... And they might even not recognise that they're being coerced. [P2]

We revisit the views and sentiments expressed in these quotes in more detail below. First we turn to the UN Office of the High Commissioner for Human Rights, to explain the reasons for making assistance dependent on formal consent:

A human rights approach requires that the provision of care and support should be both informed and non-coercive. For example, victims of trafficking should receive information on their entitlements so they can make an informed decision about what to do. As discussed above, care and support should not be made conditional on cooperation with criminal justice authorities. Victims should also be able to refuse 
care and support. They should not be forced into accepting or receiving assistance. (UN OHCHR, 2010: 14)

The emphasis on unforced and voluntary acceptance of assistance is understandable: it seems obvious that the last thing anti-slavery first responders should be doing is employing the same techniques used by traffickers to violate the rights of their victims; to do so would merely compound the violation of the victim's autonomy.

However, closer examination of the consent requirement reveals that it is being applied in ways that diverge from this model. For, in the UK, the provision of assistance is conditional on consent to things other than assistance, things that those identified as victims may have good reason to refuse. For example, the National Referral Mechanism form those identified as victims are asked to sign involves a clearly stated requirement to self-identify as a 'victim of crime' and to share one's details with the police, UK Visas and Immigration, the Home Office and other agencies (National Referral Mechanism referral form, 2016). But research in other countries has shown that many are reluctant to self-identify as victims for a variety of possible reasons, all of which inhibit their willingness to consent. ${ }^{10}$

Like other victims of or witnesses to organized crime, victims of trafficking can be subject to threats and negative conditioning by traffickers which, together with a fear of the 'authorities' can lead to reluctance to declare themselves a victim of crime and to engage with the criminal justice system (Home Office, 2014). Some are in love with their traffickers and do not want to expose them to criminal penalties (Bovenkerk et al (2006). In some

\footnotetext{
${ }^{10}$ It is not possible to make reliable claims about which of the consent-inhibiting conditions identified by researchers elsewhere apply to travellers arriving in the UK, because there is no systematic research on the factors influencing the decisions of those identified as victims at the border to give or withhold consent. Research of this kind, giving voice to victim experiences, is clearly sorely needed.
} 
cases, victims of trafficking face huge debts already that they need to work to pay off, and do not want the financial burden to fall on their families (Warren, 2012: 112). In others, they may be waiting to receive unpaid wages, which would be placed at risk by their acceptance of assistance (Rende Taylor and Latonero, 2018: 11). And research in Eastern Europe revealed that many victims of trafficking are not willing to take on a label that they see as stigmatizing, and which might lead to social rejection in their home community (Brunovskis and Surtees, 2012).

But fear of reprisals, penalties, or stigmatisation are not the only reasons why those identified as vulnerable may be reluctant to self-identify as victims of trafficking. Ethnographic work in the USA has shown that migrants who would qualify as 'potential victims of trafficking' may simply not see themselves as victims at all, sometimes because they have chosen to take on dangerous and exploitative work as an improvement on what other life was on offer (Dejanova and Raghavan, 2013; Davies: 2009). Some see the exploitative or even abusive conditions they are subjected to as an unfortunate job choice and view themselves not as victims but as active agents (Warren, 2012: 11-13). In sum, the current reliance on a simplistic binary categorization of debased victim/fully autonomous agent fails to recognise the many ways in which those trafficked exercise agency and choice even in situations of dire coercion and exploitation (Kempadoo, 2017; O'Connell Davidson, 2015; Tietjens-Mejers; 2014). Making the offer of help dependent on self-identification as a 'victim' therefore sits uncomfortably with the aim of restoring dignity and autonomy and helping people take control over their lives. ${ }^{11}$

\footnotetext{
${ }^{11}$ Similar tensions have been identified in the policing of domestic violence in the UK, especially around the requirement imposed on police to complete intelligence forms that involve probing victims for sensitive details and sharing information with other agencies, including social services. This has strained the relationship of
} 
What is more, there are reasons to question the extent to which either the refusal or the giving of consent to referral through the National Referral Mechanism meets the conditions for validity that normally apply to other policy contexts in which consent is sought- namely capacity to consent and sufficient information about the consequences of consenting or not consenting. Psychological and cognitive factors resulting from traumatization, such as posttraumatic stress disorder (Ottisova et al, 2017; Helen Bamber Foundation, 2017: 6-7) as well as the inevitable language difficulties can affect the capacity of those trafficked to consent to assistance (Bruovskis and Surtees, 2012). Addressing these issues well enough to secure meaningful consent requires frontline professionals to receive trauma training, and to have sufficient time to build a relationship of trust with those identified as victims (Helen Bamber Foundation, 2017: 2-4); Border Force Officers have neither. To make things worse, Border Force Officers are themselves too poorly informed about what happens to victims as a result of their decision to consent or to refuse to be able in turn to render the consent informed enough to be meaningful (Lynch and Hadjimatheou, 2017). Yet, even if they were better informed, the question of how they should represent the possible outcomes to those identified is not straightforward. The potential benefits to victims of referral through the National Referral Mechanism are by no means obvious. For example, two highly critical recent reports have revealed that many of those who receive government support as victims do so for only 45 days, after which they are either returned home or left destitute (Human Trafficking Foundation, 2016; UK Parliament Work and Pensions Committee, 2017). Of those left destitute, a significant number end up returning to their exploiters and being re-trafficked (Ibid, 2017).

trust between victims and police and has potentially discouraged some victims from being more open with police, in ways that may affect their safety and wellbeing in the longer term (Loftus, 2009:135-5) 
How then, is the requirement to gain consent negotiated by Border Force Officers, in the light of such challenges? We found evidence of both attempts to resist the refusal by deploying paternalistic strategies, and to rationalize it as a fully informed and autonomous exercise of choice on the part of the person trafficked:

If that adult decides that they don't want to be part of the National Referral

Mechanism and you know that where they're going, it may not be the most safe place, you have to accept that not everyone wants your help. [P7]

This strategy of rationalization contrasts with that of resistance, described to us by other Border Force Officers. A number of respondents complained that the need to obtain consent from victims of trafficking represented an unwelcome departure from previous practice in the Children and Young Persons team. The Safeguarding and Anti-Trafficking officers we spoke to expressed a desire to pressure victims into accepting assistance, reflecting the kind of 'caring paternalism' McCarthy has described, involving 'wellintentioned attempts to formulate some sense of action being taken to help individuals' (McCarthy, 2014: 82). One senior Safeguarding and Anti-Trafficking officer reported making efforts at a strategic level to challenge it but being blocked by 'lots of legal stuff around consent for adults and human rights' [P8].12 However, as the quotes at the beginning of this section illustrate, they also deploy coercive powers, such as subjecting victims to forced returns to their country of origin in the name of their own protection, despite the fact that

\footnotetext{
${ }^{12}$ Though we did not find evidence to corroborate this, in 2013 the UK's Anti-Trafficking Monitoring Group reported that they had seen evidence of first responder attempts to bypass consent by giving potential victims a blank National Referral Mechanism form to sign.
} 
there is little evidence suggesting that forced returns are indeed a protective measure (Lynch and Hadjimatheou, 2017).

This lurching between resistance and rationalization reflects the contradictory demands on Border Officers of a policy that requires them to act as humanitarian first responders but equips them to do so only with the powers and tools of law enforcement. The reality is that currently Border Officers are not encouraged to reflect on how their actions ultimately contribute to the protection of people's rights. Border Officers typically receive no feedback about what happens to those who they attempt to identify as trafficked (Lynch and Hadjimatheou, 2017). ${ }^{13}$ Instead, the highly charged rhetoric of humanitarian opportunism deflects attention away from the question of long-term assistance to the more manageable issue of identification and recognition. The recent report by the Chief Inspector of Borders is a prime example of this.

As the discussion in this section illustrates, the issue of consent raises profound questions about what the Modern Slavery Strategy does for those identified as victims and how it does it. The government's approach to anti-trafficking first response insists first and foremost on the importance of taking advantage of humanitarian opportunities to identify and recognise those trafficked 'as victims'. Yet while this rightly emphasizes the missed opportunities and potential harms of a failure to recognize victims as such, it begs the question of what good

\footnotetext{
${ }^{13}$ The new statutory 'duty to notify', which came into force after the research for this paper was conducted, introduces a potential source of feedback and monitoring for Border Force, by mandating the recording and reporting to central government each case in which an Officer identifies someone as a potential victim of trafficking but does not, for whatever reason, refer them through the National Referral Mechanism. Notifications are anonoymous unless those identified as potential victims agree to be identified. For further details see the UK government's Duty to Notify webpage at: https://www.gov.uk/government/publications/duty-to-notify-the-home-office-of-potential-victims-ofmodern-slavery
} 
recognition does for victims. What does and what should it mean to treat someone as a 'victim of trafficking'? These questions are not easily answered, partly because the experiences of coercion and exploitation and the individual needs of those trafficked can be so diverse in practice- a fact that reflects how wide an umbrella the term 'trafficking' or 'slavery' has become. Clearly, much more work needs to be done, both by researchers and by those in the human rights anti-trafficking movement, to explore both the form that the consent requirement takes in practice and the role it should play in approaches to antislavery. Such work should consider not only how respect for autonomy might be achieved in such challenging circumstances, but also how much weight it should be given in the light of competing considerations. This means re-examining the proper role of paternalism, 'caring' or otherwise, in anti-slavery policy and practice, including by giving voice to those trafficked about their experiences with the consent requirement. It also means reconsidering the current practice of requiring those identified as trafficked to adopt the questionable label of 'victim' as a condition of protection and support.

More generally, the discussion in this section serves to highlight just how difficult it is to do effective humanitarian anti-slavery work at the border, which despite the political rhetoric and the efforts of individual anti-trafficking teams remains above all a site of migration and security control.

\section{Conclusion}

Much has been written about the contradictions between humanitarian anti-slavery policy and hardline approaches to immigration control and security (Perkowski, 2016; O'Connell Davidson, 2015, 2017; Sharma, 2017). By articulating and unpicking the rationale of 
humanitarian opportunism, this paper has provided some insight into one of the most recent ways in which security and humanitarian policy aims are represented as consistent, even complementary, by government. By exploring the experiences of those on the frontline attempting to implement both victim protection and immigration control, it has shed light on some unacknowledged sources of enduring conflict between these policies. The casualties of these conflicts are, of course, those trafficked. But, in contrast to what is implied by the recent criticism of the UK Border Force, the source of the persistent failures in their protection lies in these contradictory policies, rather than merely a failure of first response.

\section{Bibliography}

Aas, K. (2011). ‘Crimmigrant Bodies and Bona Fide Travelers: Surveillance, Citizenship, and Global Governance'. Theoretical Criminology 15 (3), 331-346.

Aas, K and Gundhus, H. (2015) 'Policing Humanitarian Borderlands: Frontex, Human Rights, and the Precariousness of Life'. British Journal of Criminology, 55 1-18.

Anti-Trafficking Monitoring Group (2013). 'Hidden in plain sight. Three years on: updated analysis of UK measures to protect trafficked persons.'

http://resourcecentre.savethechildren.se/sites/default/files/documents/hidden in plain si ght.pdf (Accessed 02/07/2017) 
Aradau, C. (2004) 'The perverse politics of four-letter words: Risk and pity in the securitisation of human trafficking'. Millennium: Journal of International Studies. 33(2): 251277.

Brunovskis, A and Surtees, R. (2012) 'Out of Sight? Approaches and Challenges in the Identification of Trafficked Persons'. Fafo/Nexus Institute Project.

https://nexushumantrafficking.files.wordpress.com/2015/03/out-of-

sight identification nexus.pdf (Accessed 04/17/2017)

Balch, A and Geddes, A. (2011). 'Opportunity from Crisis? Organisational Responses to Human Trafficking in the UK'. British Journal of Politics and International Relations, Vol. 13, 26-41.

Beck, U. (1992) The Risk Society: Towards a New Modernity. (London: Sage Publishing) Bovenkerk F, van San M, Boone M, Boekhout van Solinge T, Korf D (2006) Loverboys of Modern Pooierschap. Uitgeverij Augustus, Amsterdam

Brunovskis, A and Surtees, R. 2012. Out of Sight? Approaches and Challenges in the Identification of Trafficked Persons. Fafo/Nexus Institute Project.

https://nexushumantrafficking.files.wordpress.com/2015/03/out-of-

sight identification nexus.pdf (Accessed 04/11/2017)

Carvahlo, H. (2017) The Preventive Turn in Criminal Law. (Oxford University Press)

Choi-Fitzpatrick, A. (2015) 'From Rescue to Representation: A Human Rights Approach to the Contemporary Antislavery Movement' Journal of Human Rights, 14:486-503

Council of Europe. (2005). Council of Europe Convention on Action Against Trafficking of Human Beings. 
https://rm.coe.int/CoERMPublicCommonSearchServices/DisplayDCTMContent?documentld

$=090000168008371 d($ Accessed 01/11/2016)

Dejanova, T. and Raghavan, C. (2013) 'Report from the field: evaluating an alternative to incarceration program for "highly probable trafficking victims"' Dialectical Anthropology, 37

(2) 291-28)

Dworkin, R. (1984) 'Rights as Trumps' in Waldron, J. (ed.) Theories of Rights, (Oxford: Oxford University Press). pp.153-67.

Etherington, K. (2004) Becoming a Reflexive Researcher: Using our selves in research, London, Jessica Kingsley.

Frontex (2012) Anti-Trafficking Training for Border Guards. Trainer's Manual.

http://frontex.europa.eu/feature-stories/combating-human-trafficking-at-the-bordertraining-for-eu-border-guards-rRzpfl (Accessed 04/07/2017)

Goodey, J. (2003) Migration, Crime and Victimhood: Responses to Sex Trafficking in the EU' Punishment and Society, 5(4).

Hadjimatheou and Lynch (2017) 'Once They Pass You, They May be Gone Forever: Humanitarian Duties and Professional Tensions in Safeguarding and Anti-Trafficking at the Border' British Journal of Criminology, 57(4), 945-963

Ham, Julie, Segrave, Marie, Pickering Sharon (2013) ' In the Eyes of the Beholder: Border enforcement, suspect travellers and trafficking victims' Anti-Trafficking Review Helen Bamber Foundation (2017) 'Identifying, referring and supporting victims of modern slavery in the UK through the National Referral Mechanism' Submission to the Independent Anti-Slavery Commissioner Consultation. 30 ${ }^{\text {th }}$ June, 2017. http://www.helenbamber.org/wp- 
content/uploads/2017/08/IASC-Consultation-on-NRM-Helen-Bamber-Foundation-30-June2017.pdf (Accessed 11/6/2018)

Her Majesty's Government (2015) Modern Slavery Strategy.

https://www.gov.uk/government/uploads/system/uploads/attachment data/file/383764/

Modern Slavery Strategy FINAL DEC2015.pdf (Accessed 30/7/2016)

Home Office (UK). (2016b) Victims of Modern Slavery, Frontline Staff Guidance.

https://www.gov.uk/government/uploads/system/uploads/attachment data/file/509326/vi

ctims-of-modern-slavery-frontline-staff-guidance-v3.pdf (Accessed 4/11/2016)

Human Trafficking Foundation. (2016). 'Day 46: Is There Life After the Safe House for Victims of Modern Slavery?'

http://www.humantraffickingfoundation.org/sites/default/files/Human\%20Trafficking\%20F oundation\%20Report\%202016\%20Day\%2046.PDF

Independent Chief Inspector of Borders and Immigration (2017) An Inspection of Border Force's Identification and Treatment of Potential Victims of Modern Slavery. July-October 2016. At http://icinspector.independent.gov.uk/wp-content/uploads/2017/02/PotentialVictims-of-Modern-Slavery- Inspection-report.pdf

Kempadoo, K. (2017) 'Bound Coolies' and Other Indentured Workers in the Caribbean: Implications for debates about human trafficking and modern slavery'. Anti-Trafficking Review, Issue 9. 48-63

Lipsky, M. (2010) Street Level Bureaucracy: Dilemmas of the Individual in Public Services. 30th Anniversary Expanded Edition. (New York: Russell Sage Foundation) 
Local Government Association (2017) 'Public needs greater awareness of modern slavery, say councils and fire and rescue authorities'. Press Release, 24 March, 2017. At

\section{https://www.local.gov.uk/about/news/public-needs-greater-awareness-modern-slavery-}

\section{say-councils-and-fire-and-rescue}

Loftus, B. (2009) Police Culture in a Changing World, Oxford: Oxford University Press

Lynch and Hadjimatheou (2017), ‘Acting in Isolation: Safeguarding and Anti-Trafficking Officers' Evidence and Intelligence Practices at the Border' Anti-Trafficking Review, Vol.8

Lyon, D. (2007) 'Surveillance, Security and Social Sorting: Emerging Research Priorities' International Criminal Justice Review, 17(3)

Massey, S. and Colucello, R. (2015). 'Introduction' in S. Massey et al. (eds.), Eurafrican Migration: Legal, Economic and Social Responses to Irregular Migration. Springer.

May, T. (2016) 'My Government will lead the way in defeating modern slavery' in The Telegraph Newspaper, 30 July, 2016. At http://www.telegraph.co.uk/news/2016/07/30/wewill-lead-the-way-in-defeating-modern-slavery/?mc cid=240d07b7fe\&mc eid=[UNIQID] Maynard-Moody, S and Musheno, M. (2000) 'State Agent or Citizen Agent: Two Narratives of Discretion'. Journal of Public Administration Research and Theory 10 (2): 329-358 McAdam, M. (2013) 'Who's Who at the Border? A Rights-Based Approach to Identifying Human Trafficking at International Borders'. Anti-Trafficking Review. 2: 33-49 McCarthy, D. (2014) 'Soft' Policing: The Collaborative Control of Anti-Social Behaviour. Palgrave Macmillan. 
McLaughlin, C. (2017) 'They don't look like children': child asylum-seekers, the Dubs amendment and the politics of childhood, Journal of Ethnic and Migration Studies, DOI: $10.1080 / 1369183 X .2017 .1417027$

National Crime Agency (UK). Human Trafficking: National Referral Mechanism Statistics, End of Year Summary 2016. http://www.nationalcrimeagency.gov.uk/publications/788-nationalreferral-mechanism-statistics-end-of-year-summary-2016/file (Accessed May 26th, 2017). National Referral Mechanism, UK. Referral form for adult victims of trafficking, 2016. At https://www.gov.uk/government/uploads/system/uploads/attachment data/file/631200/A dult-NRM-v.3.0.pdf

O'Connell Davidson, J. (2015) Modern Slavery: The Margins of Freedom (Palgrave MacMillan UK)

O'Connell Davidson, J. (2017) 'The right to locomotion? Trafficking, Slavery and the State' in Kotswaran, P. (Ed) Revisiting the Law and Governance or Trafficking, Forced Labor, and Modern Slavery. Cambridge.

Ottisova et al. (2016) 'Prevalence and risk of violence and the mental, physical and sexual health problems associated with human trafficking: an updated systematic review' Epidemiology and Psychiatric Sciences, 25(4): 317-341

Perkowski, Nina (2016) Deaths, Interventions, Humanitarianism and Human Rights in the Mediterranean 'Migration Crisis', Mediterranean Politics, 21(2), 331-335 Pescinski, J. (2015) 'A Human Rights Approach to Human Trafficking'. Our World: United Nations University Magazine. http://ourworld.unu.edu/en/a-human-rights-approach-tohuman-trafficking (Accessed April 20th, 2017). 
Pickering, S and Ham, J. (2014) 'Hot Pants at the Border: Sorting Sex Work from Trafficking'. British Journal of Criminology, 54 (1): 2-19.

Pratt, A and Thompson, S.K. (2008) 'Chivalry, 'race' and discretion at the Canadian border'. British Journal of Criminology, 48(5): 620-640.

Rende Taylor, L.M, and Latonero, M. (2018) 'Updated Ethics and Human Rights in AntiTrafficking: Ethical Standards for Working with Migrant Workers and Trafficked Persons in the Digital Age'. Issara Institute, Bangkok.

Sandberg, S. (2010) 'What Can 'Lies' Tell Us About Life? Notes Towards a Framework of Narrative Criminology'. Journal of Criminal Justice Education. 21(4): 447-465.

Sharma, N. (2017) The New Order of Things": Immobility as Protection in the Regime of Immigration Controls', Anti-Trafficking Review, Issue 9: 31-47

Squire, V. (2017) "Governing migration through death in Europe and the US: Identification, burial, and the crisis of modern humanism", European Journal of International Relations.

Tiejens-Meyers, D. (2014) ‘Feminism and Sex Trafficking: Rethinking Some Aspects of Autonomy and Paternalism' Ethical Theory and Moral Practice, 17, 427-441.

United Nations Human Rights Based Approach Portal. http://hrbaportal.org/

Warren, K. (2012) 'Troubling the Victim/Trafficker Dichotomy in Efforts to Combat Human Trafficking: The Unintended Consequences of Moralizing Labor Migration' Indiana Journal of Global Legal Studies, 19 (1), 105-120

Weitzer, R. 'The Social Construction of Sex Trafficking: Ideology and Institutionalization of a Moral Crusade' Politics \& Society, 35(3): 447-475 
Work and Pensions Select Committee, UK Parliament. (2017) Victims of Modern Slavery. At: https://publications.parliament.uk/pa/cm201617/cmselect/cmworpen/803/80302.htm 